\title{
Codes of practice: the implications for job advancement
}

\author{
Ron Marsden \\ National Development and Management Foundation, Johannesburg
}

The various codes of practice proposed and applied as guidetines regarding employee rights in South Africa are discussed. There are three groups of codes: codes developed by com. panies, 'internal codes' developed by other South African organizations such as SACCOLA and TUCSA, and 'external codes' imposed on South African employers from abroad, like the Sullivan principles. While all codes aim at removing discrimination in the work place, local codes focus mainly on economic and some social aspects, and external codes have a stronger political intent. Many problems still exist with the measuring and monitoring of the implementation of these employment codes, sometimes done in-company, sometimes by independent externat organizations. Generally trade unions support the codes, some seeing codes as a tool to increase union recognition and power. The codes, however, also have some dysfunctional aspects, because they can shift the focus and priority away from education and training, the allimportant factor in Black advancement.

S. Afr. J. Bus. Mgmt. 1981, 12: $109-114$

Die verskillende gebruikskodes wat voorgestel en toegepas word as riglyne wat betref werknemersregte in Suid.Afrika word bespreek. Daar is drie soorte kodes: die wat deur maat skappye ontwikkel is, 'interne kodes' ontwikkel deur ander Suid-Afrikaanse organisasies Soos SACCOLA en TUCSA, en 'eksterne kodes' wat van oorsee vir Suid-Afrikaanse werkgewers voorgeskryf word, soos die Sullivan-beginsels. Terwyl alle kodes gerig is op die verwydering van diskriminasie in die werksituasie, konsentreer plaaslike kodes meestal op ekonomiese en sommige sosiale aspekte en het eksterne kodes 'n sterker politieke oogmerk. Baie probleme bestaan nog met die meting en opvolging van die implementering van hierdie indiens-kodes, soms binne maatskappye gedoen, soms deur onafhanklike eksterne organisasies. Vakbonde ondersteun in die algemeen die kodes, sommiges sien hulle as ' $n$ hulpmiddel om vakbond-erkenning en -mag te bevorder. Die kodes het egter ook sekere disfunksionele aspekte, omdat hulle die fokus en prioriteit van onderrig en opleiding, dié belangrikste faktor in Swart vooruitgang, kan wegskuif.

S.Afr. Tydskr. Bedryfsl. 1981, 12: $109-114$

A paper delivered at Unisa SBL Seminar 'Black Advancement - the reality and challenge', Pretoria, May $21-22,1980$.

\section{Ron Marsden}

General manager, National Development and Management Foundation,

P.O. Box 31793, Braamfontein 2017, RSA

\section{Introduction}

The term 'code of practice' is a misnomer - in many cases they are guidelines or principles. However, in all cases they deal with employee rights. Not one code I have read mentions employer rights. I wonder if a more suitable title may not be 'A Code of Employee Rights'. There are to my knowledge approximately 16 codes of practice around in South Africa - there may be more. In the mid-seventies, it seemed a new profession had arisen - professional code writer. It is interesting to note all the overseas codes are aimed at one small area on the global map, namely South Africa. One could deduce from this that everywhere else in the world is rosy - only South Africa has labour problems that require a code. It is true to say that many of the countries from which these codes originate would not stand in a very good light if the focus were turned inwards to measure their own progress. One shudders to consider the results of monitoring the codes in many third world countries.

This is not an introduction to a premise that everything in the garden is rosy in South Africa - far from it. There is widespread discriminatory practice in the work place, and it is not all based on race. Any realistic survey would also give evidence of general discrimination against women. It can be argued that is is an inditement on South African managers in commerce and industry that codes had to be written at all. The track records of many companies show very little to be proud of. Frequently we have heard the statement 'Ah yes, but the government will not allow us to do that' - a nice excuse for wanting to do nothing.

\section{Codes in general}

We must not run away with the idea that all the codes are the same - they are not. They can be broken down into basically three groups, namely external, internal and company codes.

Company codes: One is tempted to think that codes of practice originated with the principles of the Rev. Leon Sullivan. This probably arises through his association with civil rights issues over the last two decades. In fact the endorsement of the Sullivan principles by US firms with affiliates in the Republic of South Africa was as recent as March 1977. Long before this, and certainly by the early 70 s, a number of leading South African com- 
panies had instituted 'codes'. They were not called that - thus they missed the accolade of originator. Look back at the chairmen's statements in the annual reports of a number of large South African companies, and you will see statements regarding their employment practices figuring prominently - SA Breweries, Anglo Vaal, Barlow Rand, Anglo American, to name only the larger ones. Similar statements can also be found in a number of overseas affiliated companies.

Internal codes: In December 1976, the President of the Cape Chamber of Commerce invited all members to join in a programme of total and genuine non-discrimination against their employees. Although taking the form of a manifesto, it was the earliest non-company South African code. In December 1977, the Urban Foundation/ SACCOLA code was published. Two other major South African codes are the TUCSA Code of Conduct and the South African Council of Churches code.

External codes: As previously indicated, the Sullivan principles were launched in March 1977. This appeared to unleash a virtual barrage of codes - the British Company Guidelines, the European Economic Community Code of Conduct, the Canadian Government Code of Conduct. Suddenly everyone was 'in on the code act'.

In general, the internal and external codes covered eight major areas, namely desegregation, employment practices, remuneration, training, development, social responsibility, trade unions and migratory labour. Table 1 shows a comparison of eight of these codes in the eight major areas. I am indebted to TUCSA for allowing me to use the comparison in their directory ${ }^{1}$ for compiling part of this chart. It is of interest to note that all the codes do not cover all the areas. For example Sullivan, Urban Foundation and TUCSA are somewhat silent on migratory labour. Possibly of more significance few of the codes are quantified in measurable terms. This may be a good or bad thing, depending on your point of view, but generally things which are not quantified or quantifiable are not measurable. This has led to a number of writers indicating the codes are little other than a pious hope or philanthropic ideal.

\section{What is the intent of the codes?}

The time is opportune to ask ourselves what the intent of the writers of the codes was. Here I am treading on dangerous ground, trying to visualize the intent without having the inner sight from the sanctum where they were drawn up.

$\rightarrow I$ think it fair to say that the business codes relate to removing all discriminatory practices in the work place.

$\rightarrow$ To select, promote and reward on merit and ability. The Cape Chamber of Commerce, the Urban Foundation and TUCSA codes seem to my mind to follow a similar intent - that is primarily economic with some social aspects. It is when we get to the external codes that things get a little 'hairy'. It is difficult to distinguish between the political, social and economic intent. Very little has been written, with the exception of Rev. Leon Sullivan, on how the codes were formulated. In the case of the Sullivan principles we have the Rev. Leon Sullivan's statement of purpose to give us some insight. Taking a few quotes from this statement:" 'It is important that there be a clear understanding that my main objective which, briefly, is the end to apartheid in South Africa. My reason for involvement in the South African situation is a moral one, and one that $I$ have the responsibility to address as a clergyman. The inhumane effect of that system on Blacks, I believe, cannot and should not be tolerated and must be attacked by persons and organizations from all walks of life and from all parts of the globe'.

Later in his statement, he indicates how he first announced his intention: 'Therefore, fully conscious of the odds against succeeding, I made the announcement one Sunday morning to members of my congregation in Philadelphia of the attempt I was about to initiate and asked for their support and their prayers. I have urged them (the signatories) to take a stand against all forms of racial discrimination and to lobby for an end to the apartheid system itself. I still have hopes that the Principles, and their vigorous implementation, can serve as a major step in a growing world effort to bring an end to racial discrimination and the apartheid system.'

It would appear from these statements that the major intent is political with economic and social aspects as secondary.

The other North American code 'Code of Conduct concerning the Employment Practices of Canadian Companies Operating in South Africa', studiously avoids in its preamble any reference to systems other than the economic one. ${ }^{3}$

Very little has been published on the meeting of the Foreign Ministers of the European Community which led to the adopting of the EEC code on September 20, 1977. A press notice issued by the UK Department of Trade in February 1979, on the assessment of reports submitted by British companies, referred only to economic factors. ${ }^{4}$

In a written reply by Mr John Smith, Secretary of State for Trade, to a question asked in the House by $\mathrm{Mr}$ George Rodgers, Mr Smith referred essentially to economic issues in the reports submitted. ${ }^{5}$ However, he did refer in a number of places to the inability of companies to meet certain requirements under present South African legislation.

It is probably fair to say the hidden hand of Commerce and Industry has played a part in many overseas codes, in keeping these codes primarily orientated to economic factors. According to Schmidt, ${ }^{6}$ even the Sullivan Principles, which from Sullivan's statement, appear to have strong political connotations, were turned down in the final draft. Schmidt states the initial draft read: 'Where the implementation requires a modification of existing South African laws and customs, we will seek modification through appropriate channels'. The final draft deleted 'changing laws and customs' and spoke only of modifying 'working conditions'.

This realism of attention to economic factors was further substantiated by the South African Ambassador to the United States, Donald Sole, when he told Princeton University's Forerunner magazine: 'I do not think they (American Corporations) will play any role in what you refer to as "elimination of apartheid", . . . they cannot play any role whatsoever in the institution of Black majority rule, ...' Thus it would appear the intent of the 
majority of codes is for improvement in practices in the economic sector with some attention to social aspects.

It may appear in this discussion, I have given undue weight to the Sullivan Principles. If this is so now or during the remainder of this paper, it is because far more has been published on this 'code'. To put it in its true perspective, however, we must remember American cor- porations employ only one percent of the total black labour force - approximately 70000 workers out of a black population of 18,6 million. The 12 largest companies, accounting for three-quarters of American capital in South Africa, are highly capital intensive, they maintain a ratio of capital to employees that is five times the overall average of companies in South Africa.

Table 1 Comparison of eight major codes in terms of eight considerations

\begin{tabular}{|c|c|c|c|c|c|c|c|c|}
\hline & $\begin{array}{c}\text { Sullivan Code } \\
\text { (United States of } \\
\text { America) } \\
\end{array}$ & $\begin{array}{c}\text { British Companies } \\
\text { Guidelines }\end{array}$ & $\begin{array}{c}\text { European Fconomic } \\
\text { Community Code } \\
\text { of Conduct }\end{array}$ & $\begin{array}{l}\text { Cape Chamber } \\
\text { of Commerce }\end{array}$ & $\begin{array}{c}\text { South African } \\
\text { council of Churches }\end{array}$ & $\begin{array}{l}\text { Urban Founda- } \\
\text { tion SACCOLA }\end{array}$ & $\begin{array}{l}\text { Canadian Govern- } \\
\text { men! Code of } \\
\text { Conduct }\end{array}$ & $\begin{array}{l}\text { TLCSA Code } \\
\text { of Conduct }\end{array}$ \\
\hline Desegregation & $\begin{array}{l}\text { Eliminate all vestiges } \\
\text { of racial discrimina- } \\
\text { tion, remove all race } \\
\text { discrimination signs, } \\
\text { desegregate all } \\
\text { eating, comfort and } \\
\text { work facilities. }\end{array}$ & $\begin{array}{l}\text { Aim at non-segrega- } \\
\text { tion but duplicalion } \\
\text { of facilities if sepa- } \\
\text { ration, required by } \\
\text { law. }\end{array}$ & $\begin{array}{l}\text { Encourage collective } \\
\text { bargaining with } \\
\text { African workers. } \\
\text { Recognize African } \\
\text { trade unions where } \\
\text { they exist. }\end{array}$ & & $\begin{array}{l}\text { Non-segregation of } \\
\text { races in all eating, } \\
\text { comfort and work } \\
\text { facilities. }\end{array}$ & $\begin{array}{l}\text { Removal of discrimi. } \\
\text { nation in all aspecis } \\
\text { of employment } \\
\text { policy. }\end{array}$ & $\begin{array}{l}\text { Integrate working. } \\
\text { eating, recreational. } \\
\text { educational and } \\
\text { training facilities. }\end{array}$ & $\begin{array}{l}\text { Non-discrimination } \\
\text { in the work place. } \\
\text { in regard to the phy- } \\
\text { sical surroundings } \\
\text { and to canteen and } \\
\text { rest-room facilities. }\end{array}$ \\
\hline $\begin{array}{l}\text { Employment } \\
\text { practices }\end{array}$ & $\begin{array}{l}\text { Equal and fair terms } \\
\text { and conditions of } \\
\text { employment, provide } \\
\text { non-discriminatory } \\
\text { eligibility for benefit } \\
\text { plans. Support elimi- } \\
\text { nation of all indus- } \\
\text { trial racial discrimi- } \\
\text { natory laws. }\end{array}$ & $\begin{array}{l}\text { Fringe benefits for } \\
\text { Blacks. No discrimi- } \\
\text { nation in any sphere } \\
\text { of work including } \\
\text { promotion. }\end{array}$ & $\begin{array}{l}\text { Improvement of } \\
\text { fringe benefits for } \\
\text { African workers. No } \\
\text { discrimination in any } \\
\text { work sphere inclu- } \\
\text { ding promotion. }\end{array}$ & $\begin{array}{l}\text { Select, employ, train } \\
\text { and promolewithout } \\
\text { regard to tace or } \\
\text { colour. Benefits to } \\
\text { all. }\end{array}$ & $\begin{array}{l}\text { Equal and fair cm. } \\
\text { ployment practices } \\
\text { for all employees. }\end{array}$ & $\begin{array}{l}\text { No discrimination } \\
\text { based on race or } \\
\text { colour in job ad. } \\
\text { vancement and } \\
\text { fringe benefits. }\end{array}$ & 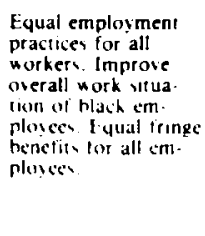 & $\begin{array}{l}\text { Non-diwcimination } \\
\text { in engagement, re- } \\
\text { trenchment or pro. } \\
\text { motion of staff. } \\
\text { Equal fringe benefiis } \\
\text { e for all employees eg. } \\
\text { penston schemes, } \\
\text { medical aid whemes. } \\
\text { annual leave. sisk } \\
\text { leave. els. }\end{array}$ \\
\hline Remuneration & $\begin{array}{l}\text { Equal pay for all em- } \\
\text { ployees doing equal } \\
\text { or comparable work } \\
\text { for the same period } \\
\text { of time. Ensure equi- } \\
\text { table system of job } \\
\text { classification. Mini- } \\
\text { mum wages to be } \\
\text { well above the appro- } \\
\text { priate local minimum } \\
\text { economic living } \\
\text { level. }\end{array}$ & $\begin{array}{l}\text { Fair wages above } \\
\text { Poveriy Datum Line } \\
\text { and equal pay for } \\
\text { equal work. Reduce } \\
\text { wage gap. }\end{array}$ & $\begin{array}{l}\text { Companies to assume } \\
\text { responsibility as re- } \\
\text { gards African em- } \\
\text { ployees. Minimum } \\
\text { wages to exceed ini- } \\
\text { tally minimum sub- } \\
\text { sistence levels by at } \\
\text { least } 50 \% \text {. Equal pay } \\
\text { for equal work. }\end{array}$ & $\begin{array}{l}\text { Determine salaries, } \\
\text { wages on principle of } \\
\text { equal pay for equal } \\
\text { work. }\end{array}$ & $\begin{array}{l}\text { Equal pay for all do- } \\
\text { ing equal or com- } \\
\text { parable work. }\end{array}$ & $\begin{array}{l}\text { Elimination of dis- } \\
\text { crimination based on } \\
\text { race or colour. }\end{array}$ & $\begin{array}{l}\text { Equal pay for equal } \\
\text { work. Emplovers } \\
\text { should aim to pas } \\
\text { above minimum da- } \\
\text { tum lines for worker } \\
\text { in lowest categories. } \\
\text {. }\end{array}$ & $\begin{array}{l}\text { To promote the crea- } \\
\text { tion of employment } \\
\text { opportunities for all } \\
\text { South Africans irre- } \\
\text { spective of race or } \\
\text { colour at wage levels } \\
\text { which will enable the } \\
\text { workers to maintain } \\
\text { civilized standards } \\
\text { of living. }\end{array}$ \\
\hline Training & $\begin{array}{l}\text { Initiation and de- } \\
\text { velopment of train- } \\
\text { ing programmes } \\
\text { that will prepare sub- } \\
\text { stantial numbers of } \\
\text { Blacks and other } \\
\text { non-Whites for su- } \\
\text { pervisory, admini- } \\
\text { strative clerical and } \\
\text { lechnical jobs. }\end{array}$ & $\begin{array}{l}\text { Internal or external } \\
\text { training including } \\
\text { artisan skills. } \\
\text { Stop usage of white } \\
\text { immigrant labour. }\end{array}$ & $\begin{array}{l}\text { Internal or external } \\
\text { training schemes for } \\
\text { Blacks, including to } \\
\text { artisan status. Em- } \\
\text { ployers to reduce } \\
\text { their dependence on } \\
\text { white immigrant la- } \\
\text { bour. }\end{array}$ & & $\begin{array}{l}\text { Initiation and de- } \\
\text { velopment of train- } \\
\text { ing for large scale } \\
\text { Black advancement. }\end{array}$ & $\begin{array}{l}\text { Training program- } \\
\text { mes or facilities to } \\
\text { improve productivity } \\
\text { and skill. Aim to } \\
\text { achieve Airican ad- } \\
\text { vancement into lech- } \\
\text { nical, administrative } \\
\text { and managerial po- } \\
\text { sitions. }\end{array}$ & $\begin{array}{l}\text { Provide training } \\
\text { programmes. }\end{array}$ & $\begin{array}{l}\text { Equal training, edu- } \\
\text { cational and recrea- } \\
\text { tional facilities for } \\
\text { all staff. }\end{array}$ \\
\hline Development & $\begin{array}{l}\text { Increase the number } \\
\text { of Blacks and other } \\
\text { non-Whites in } \\
\text { management and su- } \\
\text { pervisory positions. }\end{array}$ & $\begin{array}{l}\text { Encouragement of } \\
\text { training to develop } \\
\text { full potential, and } \\
\text { non-racial promo- } \\
\text { tion policy. }\end{array}$ & $\begin{array}{l}\text { Encouragement of } \\
\text { training to develop } \\
\text { full potential and } \\
\text { non-racial promo- } \\
\text { tion policy. }\end{array}$ & $\begin{array}{l}\text { Select, employ, train } \\
\text { and promote without } \\
\text { regard to race or } \\
\text { colour (as above). }\end{array}$ & $\begin{array}{l}\text { Increase number of } \\
\text { Blacks and other } \\
\text { non-Whites in mana- } \\
\text { gerial and superviso- } \\
\text { ry positions. }\end{array}$ & $\begin{array}{l}\text { No discrimination in } \\
\text { selection. empioy: } \\
\text { ment, advancement } \\
\text { or promotion of all } \\
\text { employees. }\end{array}$ & $\begin{array}{l}\text { Provide job oppor- } \\
\text { tunities to facilitate } \\
\text { movement of Blacks } \\
\text { into semi-skilled and } \\
\text { skilled positions. In- } \\
\text { troduce Blacksto su- } \\
\text { pervisory positions } \\
\text { on an acielerated ba- } \\
\text { sis rather than re- } \\
\text { cruiting expatriate } \\
\text { personnel. }\end{array}$ & $\begin{array}{l}\text { To promote sound } \\
\text { relations between } \\
\text { employees of all } \\
\text { races on the one } \\
\text { hand. and manage- } \\
\text { ment on the other. } \\
\text { in the interests of } \\
\text { building a sound } \\
\text { economy. }\end{array}$ \\
\hline $\begin{array}{l}\text { Social } \\
\text { responsibility }\end{array}$ & $\begin{array}{l}\text { Improve the quality } \\
\text { of employees' lives } \\
\text { outside of the } \\
\text { working environ. } \\
\text { ment in such areas } \\
\text { as housing, trans- } \\
\text { portation, school. } \\
\text { ing, recreation and } \\
\text { health facilitites. }\end{array}$ & $\begin{array}{l}\text { Fringe benefits to } \\
\text { aid home purchase, } \\
\text { education, food. }\end{array}$ & $\begin{array}{l}\text { Concern with living } \\
\text { conditions of } \\
\text { employees. Funds } \\
\text { to be set aside to } \\
\text { aid home purcha. } \\
\text { sing transportation, } \\
\text { recreation facilities. } \\
\text { pensions, medical } \\
\text { and other social } \\
\text { welfare facilities. } \\
\text { and to help em. } \\
\text { ployees in problems } \\
\text { with authorities } \\
\text { concerning free } \\
\text { movement. }\end{array}$ & & $\begin{array}{l}\text { Improve quality of } \\
\text { employees lives } \\
\text { outside the work } \\
\text { environment. }\end{array}$ & $\begin{array}{l}\text { Accelerate the crea- } \\
\text { tion of employment } \\
\text { opportunities at } \\
\text { wage rates to main- } \\
\text { tain visible living } \\
\text { standards. }\end{array}$ & $\begin{array}{l}\text { Encourage coim- } \\
\text { panies to assist in } \\
\text { providing medical } \\
\text { and health facilities } \\
\text { for workers and } \\
\text { families, transpor- } \\
\text { tation to and from } \\
\text { work, adequate } \\
\text { housing, education } \\
\text { for children. legal } \\
\text { assistance, unem- } \\
\text { ployment insurance. }\end{array}$ & \\
\hline Trade unions & $\begin{array}{l}\text { Acknowledge gene- } \\
\text { rally the right of } \\
\text { black workers to } \\
\text { form their own } \\
\text { union or to be re- } \\
\text { presented by trade } \\
\text { unions where unions } \\
\text { already exist. Sup- } \\
\text { port the elimination } \\
\text { of discrimination } \\
\text { against the right } \\
\text { of Blacks to form } \\
\text { or belong to a } \\
\text { government regis. } \\
\text { tered union. }\end{array}$ & $\begin{array}{l}\text { Encourage lawful } \\
\text { collective bargain- } \\
\text { ing with Blacks. }\end{array}$ & $\begin{array}{l}\text { Encourage collective } \\
\text { bargaining with } \\
\text { African workers. } \\
\text { Recognize African } \\
\text { trade unions where } \\
\text { they exist. }\end{array}$ & & $\begin{array}{l}\text { Recognition and } \\
\text { active encourage- } \\
\text { ment of trade } \\
\text { unions. }\end{array}$ & $\begin{array}{l}\text { Recognition of } \\
\text { basic rights of } \\
\text { workers: freedom } \\
\text { of association, col- } \\
\text { lective negotiation. } \\
\text { lawful strikes and } \\
\text { protection against } \\
\text { victimization. }\end{array}$ & $\begin{array}{l}\text { Companies to en- } \\
\text { sure employees free } \\
\text { to organize collec- } \\
\text { tive bargaining } \\
\text { units. Extend cus- } \\
\text { tomary basic rights } \\
\text { to such bargaining } \\
\text { units. }\end{array}$ & $\begin{array}{l}\text { Actively to press } \\
\text { employers and } \\
\text { Government to } \\
\text { recognize the right } \\
\text { of the African } \\
\text { to the same trade } \\
\text { union and collective } \\
\text { bargaining rights } \\
\text { as are presently } \\
\text { enjoved by other } \\
\text { workers, and to } \\
\text { insist that the en- } \\
\text { terprise committee } \\
\text { system can never } \\
\text { be a substitute for } \\
\text { genuine trade }\end{array}$ \\
\hline Migratory labour & & $\begin{array}{l}\text { Choose locations } \\
\text { which permit family } \\
\text { based labour. Legal } \\
\text { aid for pass } \\
\text { offenders. }\end{array}$ & $\begin{array}{l}\text { Contribute to en- } \\
\text { suring freedom of } \\
\text { movement for black } \\
\text { workers and their } \\
\text { families. Alleviate } \\
\text { effects of the } \\
\text { system. }\end{array}$ & $\begin{array}{l}\text { Employers must } \\
\text { help to ensure free- } \\
\text { dom of choice as to } \\
\text { place of work, help } \\
\text { alleviate effects of } \\
\text { migrat ory labour. }\end{array}$ & $\begin{array}{l}\text { No migrant labour } \\
\text { unless married ac- } \\
\text { commodation pro- } \\
\text { vided. }\end{array}$ & & & $\begin{array}{l}\text { unionism. To en- } \\
\text { courage and assist } \\
\text { African workers in } \\
\text { their own industries } \\
\text { to organize them- } \\
\text { selves into a trade } \\
\text { union, pending the } \\
\text { time when African } \\
\text { workers will be per. } \\
\text { mitted to become } \\
\text { members of } \\
\text { registered unions. }\end{array}$ \\
\hline
\end{tabular}




\section{Measuring and monitoring the codes}

We have indicated that a number of the internal and external codes are more guidelines or principles than codes. It is in the monitoring of these guidelines or principles that they become quantified codes. None of the codes currently carry legal penalties for non-compliance. The pressure is brought to bear where grading systems are used or some form of categorization appears. Being graded as making poor progress or categorized as paying wages well below the MLL has a social stigma attached to it and provides ammunition for voiciferous interest groups. The chairman of an overseas company with a rating of other than the very best is sure of a lively shareholders' meeting with minority shareholders demanding disinvestment in South Africa.

The business codes are extensively monitored incompany, with the chief executive usually receiving an annual report on the progress of companies within the group on agreed objectives. Frequently the group personnel function operates as a monitoring agency.

The internal codes are not currently monitored. The Urban Foundation/SACCOLA code has made an initial attempt to design a monitoring format and questionnaire. This was tried out in a pilot study and, it is understood, modified in the light of the feedback obtained. Professor Blackie Swart, Institute of Labour Relations, UNISA, stated at an NDMF seminar in March 1979 , that the Institute had been approached to act as the monitoring agency for SACCOLA. ${ }^{7}$ They had designed a model for this purpose which had led to two aspects being considered in the monitoring:

\section{- the intention of management \\ - present employment practices.}

Thus the SACCOLA monitoring system will have both quantitative and qualitative aspects. One can imagine the difficulties that are entailed in designing a questionnaire that will be acceptable to the majority of South African companies. One thing is certain, when the SACCOLA system becomes operative it will not only supply us with information on the progress of the code which covers the vast majority of South African employees, but will also supply information to counter-act the overseas detractors to the genuine progress currently being made in job advancement and other areas of the code. TUCSA has indicated it intends to monitor its code, but no formal monitoring system has become apparent at this stage. Reports by the 52 registered trade unions and seven unregistered trade unions covering 252734 individual members is one possible monitoring system which may arise.

The overseas codes are monitored in a variety of ways. The EEC code is monitored for British companies by reports to the Board of Trade. An analysis of these is then submitted to Parliament. Copies of reports may be inspected at the Department of Trade Press Office and Headquarters library. German companies report to their head offices and German trade unions play a major role in monitoring the reports.

The Sullivan Principles have probably the most complex monitoring system at this stage. In accordance with the 'Amplified Guidelines to the Statement of Principles' signatories are required to complete semi-annual compliance reports. The comprehensive questionnaires, dealing with each of the six principles, are formally assessed by Arthur D. Little. Arthur D. Little, a prestigious management consulting firm, acts as an independent monitoring agency and submits a comprehensive report to Rev. Leon Sullivan. The report grades companies into categories of achievement or progress.

A number of other agencies and interests groups based in the United States have attempted to get in on the monitoring scene. While they have created a degree of harassment to parent companies and affiliate management, they appear to have made little progress as effective monitoring agencies to date.

Some affiliates of overseas companies have gone a stage further than the basic monitoring processes. Shell was among the first of these by employing a South African university to carry out a Social Audit of its programmes. A more recent audit was carried out by the Institute of Race Relations on Ford's compliance with the Sullivan principles.

This form of auditing can increase the credibility of the companies' programmes both externally and internally. It can also indicate to the company areas where it is not making the impact or progress it believes it is making. It can also produce results which reflect on the credibility and competence of the auditing agency. We may see an increase in this form of independent auditing as companies look for increased credibility in implementing codes. However, there are very few independent organizations in South Africa with the necessary in-depth knowledge of business to produce really meaningful reports for management action.

The 'pros and cons' of monitoring can lead to endless debate. In some cases the monitoring can become so complex that the utilization of scarce management resources becomes counter-productive. It becomes something like the tax payers' dilemma: 'How do I beat the system gain most, pay least?' One senior manager heavily involved in the monitoring process said to me: 'At least the codes have taught us how to measure the effectiveness of our job advancement programmes'.

\section{The unions and the codes}

In general the trade unions support the codes, particularly those that specifically require recognition of trade unions, rights of employees to join them and collective bargaining. As we have already noted the German trade unions play an important role in the monitoring process. With their system of worker-elected directors on the boards of large companies, they have a significant say in policy, which includes the operation of affiliates in relationship to the EEC code.

TUCSA has not only provided its own code but in its 1979/80 directory, stated its support.' 'As such TUCSA welcomes these codes of practice. They embody much of that for which we have been consistently campaigning for many years.'

Some unions appear to consider that the prime reasons to being of the codes, is to promote trade unions. The Federation of South African Trade Unions (FOSATU) states: ${ }^{8}$ 'All codes must be measured against the yardstick of whether they have promoted union recognition'. In the 
same article FOSATU claims that employers have painted a distorted picture of the progress they have made in relation to the codes.

The AFL-CIO has stated its support of the Sullivan Principles. The ILO has also agreed that the overseas codes are a step in the right direction, although they appear to see them as an implement for political as well as economic and social changes. They have been fairly critical of the major South African code, the Urban Foundation/SACCOLA code, indicating that they consider it a watered down version of the overseas codes with very little teeth.

\section{Dysfunctional aspects of the codes}

Thus far we have looked at the codes of practice and related aspects in some detail. It is necessary to state my perception of these matters, before I can give you my views on their implication for Black advancement. I must stress that what follows is my personal view, based on approximately six years of experience in the specific field of job advancement with a major emphasis on the black worker.

My major premise is that the codes are dysfunctional in a number of areas - one of which is Black advancement. My argument is that where a company is measured by either an external or an internal code, (I specifically exclude company codes) the company will define some aspects of its strategy in relation to the monitoring system. Public opinion, activities of pressure groups, etc. will ensure this. Companies will strive for a favourable rating, assessment or other mark of progress.

1 have tried to show in Table 2 a comparison of priorities between the codes of practice, black worker needs and the needs of the South African economy. I am sure there are people who will disagree with my ranking. However, I am even more sure that, if each of you were to draw up a comparison based on your personal view, you would not end up with three tables in the same rank order. The point is that different interest groups have different priorities, and expect different outcomes from the implementation of codes of practice.

I argue that a company's major priority in relation to a code will be a favourable rating, or put in another way, it will strive to avoid an unfavourable rating. If you do not agree, I can assure you, when the latest ratings were released in the USA by Arthur D. Little on the Sullivan
Principles, there was a long queue of companies who had not made category I, hammering on the door to query their ratings.

To achieve a favourable rating, companies will in general look for high visibility programmes. These will achieve favourable media coverage, for example YZ Company spends $\mathbf{R} 2$ million on racially integrated facilities. This has an impact on public opinion, pressure groups, shareholders, etc. Thus I have ranked the priorities in the light of this. Pay and Training and Development are not at the top of the ranking. Pay is a high visibility item where it is low. Training and development is frequently a long-term concept, and its visibility is thus muted. Returning to pay, this can be extremely dysfunctional. Let us take a very simple example. Assume a company can afford a R1 000 a week wage bill and it has ten employees, on average each employee will earn R 100 . Now assume further that R100 is the Minimum Living Level and you are locked into a code that requires you pay $50 \%$ above the MLL. Unless you can increase your wage bill, and this has been very difficult if not impossible during the recent recession, a simple division shows that you reduce your work force by $40 \%$. I realize it is not quite as simple as this example, but all increases in wages have to be paid for somewhere, unless there is a corresponding increase in productivity. In general there has been no marked increase in productivity - if anything it is falling, in relation to wage increases over the past three years. There can be little doubt that over the past three years companies have looked very carefully before employing or replacing workers and it is my argument that where they are locked into pay/code percentages, they will tend to reduce or not replace head counts. A further strong possibility is a move from labour intensive operations, with escalating wage bills, to capital intensive operations. Not exactly desirable if you consider unemployment figures among black workers.

One of South Africa's dilemmas is a significant shortage in many work categories, and yet at the same time extensive unemployment in the black potential work force. Now is not the time to argue why this situation has arisen, but it is a fact. In general, the black workers are ill-equipped to meet our manpower shortages. They have neither the knowledge nor the skill to fill the thousands of vacancies existing today. In the mining industry, with a booming gold price, gold output is restricted by man-

Table 2 Ranking of priorities of three interest groups affected by codes

\begin{tabular}{|c|c|c|c|}
\hline Priority & Codes of practice & Black worker needs & $\begin{array}{l}\text { Economic needs of } \\
\text { South Africa }\end{array}$ \\
\hline Major & Favourable rating & Self interest & Growth \\
\hline 1 & Desegregation of facilities & Pay & Productivity \\
\hline 2 & $\begin{array}{l}\text { Social responsibility: } \\
\text { housing, schools, am- } \\
\text { menity centres, etc. }\end{array}$ & Job security & Training and development \\
\hline 3 & $\begin{array}{l}\text { Recognition: black trade } \\
\text { unions }\end{array}$ & More jobs & Worker mobility \\
\hline 4 & Pay & Equal opportunity in jobt & Job creation \\
\hline 5 & Training and development & Training and development & Housing \\
\hline
\end{tabular}


Table 3 Composition of South African community by socio-economic groups, 1978

\begin{tabular}{lcccc}
\hline Group status & $\begin{array}{c}\text { Per cent of } \\
\text { population }\end{array}$ & $\begin{array}{c}\text { Population } \\
\text { numbers }\end{array}$ & $\begin{array}{c}\text { Numerical ratio } \\
\text { of population }\end{array}$ & $\begin{array}{c}\text { Natural increase } \\
\% \text { per annum }\end{array}$ \\
\hline $\begin{array}{l}\text { 1. Executive group } \\
\begin{array}{l}\text { 2. Technician and } \\
\text { highly skilled }\end{array}\end{array}$ & 3,4 & 926000 & 1 & 0,9 \\
$\begin{array}{l}\text { 3. Semi-skilled } \\
\text { 4. Unskilled and } \\
\text { under-employed }\end{array}$ & 8,2 & 2200000 & 4 & 1,4 \\
\hline $\begin{array}{l}\text { All } \\
\text { Ratios of executives to other workers: }\end{array}$ & 55,5 & 15100000 & 22 & 2,3 \\
South Africa & 100,0 & 27226000 & & 3,1 \\
$\begin{array}{l}\text { Japan } \\
\text { Australia } \\
\text { USA }\end{array}$ & $1: 42$ & & 2,6 \\
\hline
\end{tabular}

Source: Sadie, JL. Population and Society, People and Profits, Nov. 1978, p. 12.

power shortages. While there are a number of variables in the solution to this problem, certainly one of the major ones is a massive investment in training and developing all race groups, with specific emphasis on the black worker. Yet most codes are fairly vague on objectives in this critical area and a monitoring system based on annual progress is hardly conducive to the long-term effort required in training much of our work force. For example, any investment in training a skilled person will not show any output before 22 months at the minimum, and generally in 4-5 years. I am not saying that companies who are signatories to codes are not investing in training - they are - in some cases 100000 's of rands. But, I am saying they are also investing scarce financial and other resources in a variety of other areas, dictated by the codes. I believe if more of these funds were channelled into training and development to increase our labour productivity which would increase our growth, in turn creating more job opportunities, then this cycle would generate the funds to deal with the other areas of the codes which, however important, are peripheral to the core problem of a growing economy. I therefore submit that the codes are dysfunctional to job advancement, particularly with respect to the black worker, considering what is currently being achieved and what could be achieved.

In conclusion I think there is no better picture than the figures produced by Prof. Sadie. ${ }^{9}$ (See Table 3.) In the figures, he shows that the ratio of socio-economic groups is 42:1. In the United States it is 6:1; most advanced countries are somewhere between 10-15:1. I do not know what ratio is ideal for South Africa. I do know it is not $42: 1$. We have to get that ratio down and that means advancing workers through the various levels. The ratio will not be improved by desegregation, recognizing a black union or the like, and if we do not get the ratio right and fairly quickly, codes of practice and monitoring them will be the least of our problems.

\section{References}

1. TUCSA, Trading Union Directory, 1979/80.

2. SUllivaN, L.H. Codes of Employment, the Sullivan Principles. S. Afr. Outlook, May 1979, p.67.

3. Code of Conduct Concerning the Employment Practices of Canadian Companies operating in South Africa, Canadian Government.

4. British Department of Trade, Press Notice, Feb. 5, 1979.

5. Department of Trade, Code of Conduct for Companies with Interests in South Africa, Written Parliamentary by Mr John Smith, Secretary of State for Trade, London, 1979.

6. SCHMIDT, E.S. The Sullivan Principles: Decoding Corporate Camouflage. S. Afr. Outlook, May 1979, p.73.

7. SWART, S.M. Monitoring the code: SACCOLA's role. In proceedings of NDMF Seminar: Implementing the codes of employment practice, Johannesburg, March 7, 1979, pp.82-89.

8. EEC Employment Code, FOSATU Charges. Financial Mail, Feb. 22, 1980, p.696.

9. SADIE, J.L. Population and society. People \& Profits, Nov. 1978, pp.12-14, 32 . 